\title{
MILAN ZLOKOVIĆ: OBSERVATIONS FROM PROXIMITY
}

Serbian architect and professor Milan Zloković developed his procedure of proportioning and modular coordination which he expounded in his papers and demonstrated its results in his significant architectural designs. As his son and witness of events in the life history of Milan Zloković, the Author of this paper, architect and civil engineer, presents his personal observations that may contribute to the understanding of his father's inventive and creative approach to architecture. They refer to his work in architectural design, modular coordination and theory of proportions embedded in his creative and educative activity.

ARCHITECTURE

ARCHITECTURAL DESIGN

THEORY OF PROPORTIONS

PROPORTIONING

MODULAAR COORDINATION 
Milan Zloković, the son of the naval captain of Lloyd Triestino, was born in 1898 in Trieste (Italy), at that time in Austro-Hungary till the end of the First World War. He grew up there and after the war came to Belgrade to become an architect. He designed many buildings, participated at numerous architectural competitions and was one of the leading pioneers of modern architecture as an active architect and teacher to the students. The ideas of modern architecture were widespread by his designs, writing, lectures and engagement at professional meetings, as well as by a great number of designs at competitions, where beside the awarded designs his non-awarded ones also attracted the attention of the historians of architecture (the Saint Sava Cathedral, the Terazije terrace and others).

My first perception of my father's architecture is his own house ${ }^{1,2,3}$ in Neimar area, presented in many publications as the first modern building in Belgrade in 1927, the house with a character of its own and an ambiance of the exterior and interior proportioned and coordinated with elegance. Maybe the ships, which he liked very much, inspired him to design the interior of the great room with built-in furniture.

In his design of the University Pediatric Clinic ${ }^{1,2,3,14}$ in Belgrade, the shapes of ships and their decks perhaps influenced the solution of the form of the building with terraces like the decks of a great ocean liner. During its construction my father worked hard to bring the details from his design to perfection, searching with great persistence and finding ideal colors for façade walls, windows, terrace doors and banisters. Postwar addition of stories and changes on this monument of modern architecture made an enormous damage to its beauty and perfection and we can only hope that in future all barbaric interventions will be removed and the building restored to its original condition.

I was the witness of his striving for perfection also during construction of the building of "FIAT"1,2,3 in Belgrade, where he searched for the most suitable clinker brick for coating the façade walls. After having collected a great number of samples in red nuances, he decided to use the most beautiful dark red clinker brick. However, after the war these bricks were replaced with new bricks in an ugly color.

Before the war and during my childhood I visited the hotel ${ }^{1,2,3}$ designed by my father in Mataruška Banja in Serbia, at that time in full splendor of its exterior, interior and the cinema on the roof terrace. These visual prints remained intact in my memory to this day, together with deep regret because of the cruel adaptations that ruined this architectural jewel. 
He loved Boka Kotorska (Montenegro, formerly Yugoslavia), the homeland of his ancestors, and was engaged there as a researcher and the architect, designing the hospital ${ }^{1}$ that was erected in Risan.

In the tourist complex ${ }^{14}$ in Ulcinj (Montenegro, formerly Yugoslavia), that he designed in modular coordination, I would like to point out to the beauty of the restaurant building with its exterior and interior composed in extraordinary harmony.

The Teacher Training-school ${ }^{14}$ and the Higher Teacher College, built in Prizren in Serbia, are the latest buildings designed by my father, where he strictly applied modular coordination with proportioning in design of these buildings, constructed by mounting prefabricated reinforced concrete elements.

Milan Zloković investigated composition and proportions in architecture from the past and gave his original interpretations in papers about Blondel's gate $\mathrm{e}^{4,14}$, the orders of Vignola ${ }^{8,9,14}$ and civil architecture in Boka Kotorska during the Venetian domination ${ }^{5}$. He wrote about anthropomorphic measures ${ }^{7}, 14$ the golden section ${ }^{6,14}$ and preferential numbers ${ }^{10-14}$ in architectural composition. Beside a multitude of books and reviews, I watched him sitting at his large table, composing text and drawing the images for print, writing in Serbian, German, French and Italian. Excellent knowledge of these languages was useful in his contacts with architects and researchers in Germany, France and in Italy, where he was able to lecture in the language of the respectful country.

After the forties the modular coordination in architectural design was in the field of his study and activity in the national and international organizations, conferences and at his faculty. His numerous published papers and engagement established his reputation as the leading person in the field of modular coordination in Yugoslavia. In his papers at the International Modular Group conferences he proved the necessity of the existence of links of modular coordination with architectural composition ${ }^{10,14}$, which was contrary to the crude opinion of some high foreign officials that modular coordination was an industrial tool only, rejecting its association with architectural composition, proportions and art. His concept of modular coordination and its application was explained in his papers using his own designs, where modular lines were employed in composition in three dimensions. He inspired young architects in Yugoslavia to devote themselves to research in the field of modular coordination and helped them as mentor for their doctoral degree. 
As professor of architectural design at the Faculty of Architecture in Belgrade he was successful in introducing modular coordination into architectural design, in spite of the resistance of many colleagues who were not inclined to accept it. He was very fond of work with his students, revealing to them his inspiring vision of architecture and skill of design. As a communicative person he liked to maintain the relations with his former students, who visited him in Belgrade or met abroad where they were worked.

His artistic talent was expressed also by his painting, using oil and mostly water color, as well as by drawing many portraits in pencil or in ink, which he presented at the collective exhibition of drawings, paintings and sculptures created by architects in the gallery Cvijeta Zuzorić in Belgrade after the Second World War.

As an architect and researcher in the theory of proportions, modular coordination and architectural composition, Milan Zloković conceived and developed his procedure of proportioning in architectural design. His papers and designs demonstrate that clever application of modular coordination and proportioning can produce superior results when applied with skillful utilization of modular tools and art of proportioning.

In his long last paper „La coordinazione modulare” ${ }^{14}$, published in Bari in Italia, he provided a compact exposition of his ideas about measures, proportioning and modular coordination in architectural composition, its contents including:

- Anthropomorphic measures,

- The system of golden section,

- Plato's «lambda» and its practical application in architectural orders cited by Vitruvius and Alberti,

- Regulative traces of architectural orders in the golden system,

- Antic compasses for proportioning with four fixed points for predetermined geometrical relationship,

- Modular coordination of artisans in past centuries in Dalmatia,

- An example of modular collimation in 1931: Pediatric Clinic of the Medical Faculty in Belgrade realized in prewar period,

- Relations between horizontal and vertical internal communications in examples of modular plans,

- Example of meaningful simplification of dimensioning by modular numbers in the Teacher Training-school in Prizren,

- Example of modular composition of façades of the Teacher Training-school in Prizren, 
- Example of the plan of the lodging on discontinuous design modular networks, - Program of prefabrication of modular building elements intended for the construction of tourist buildings at the coast of Montenegro,

- Example of application of modular typified elements fabricated on the building site of the tourist colony in Ulcinj.

An exceptional tribute to Milan Zloković was paid by Ljiljana Blagojević in her glorious book Modernism in Serbia ${ }^{1}$, published by the MIT Press, with superior analysis and understanding of my father's ideas and his architectural composition. England, 2003. umetnosti, Muzej savremene umetnosti, Beograd, 1989. Modernism). Prepared for print in 2010. the insufficiently clarified problem of proportions in architecture”, („Uticaj proporcijskog sistema Blondelove kapije sv. Deni u Parizu na nedovoljno rasvetljeni problem proporcija u arhitekturi). Godišnjak Tehničkog fakulteta 1946/47, pp. 45-58, Beograd, 1949. arhitektura u Boki Kotorskoj u doba Mletačke vlasti“). Spomenik CIII, Srpska akademija nauka i umetnosti, Beograd, 1953. 
Zloković, Milan, „Anthropomorphic system of measurements in architecture”, („Antropomorfni sistem mera u arhitekturi“). Zbornik zaštite spomenika kulture, Volume IV-V 1953/54, pp. 181210, Beograd, 1955.

Zloković, Milan, „Geometrical analysis of the proportional structure of the architectural orders according to Vignola” („Geometrijska analiza proporcijskog sklopa arhitektonskih redova po Vinjoli“). Zbornik Arhitektonskog fakulteta, vol. II/1956, pp. 35-73 Beograd, 1956.

Zloković, Milan, „Interpretazione modulare degli ordini del Vignola“. La casa 4, Quaderni di architettura e critica, p. 162-169, Roma, 1957.

Zloković, Milan, „Influence of modular coordination on the esthetic component in architecture”, („Uticaj modularne koordinacije na estetsku komponentu u arhitekturi“). Savetovanje o modularnoj koordinaciji u građevinarstvu. Savezni zavod za produktivnost rada, pp. 5-27, Beograd, 1958.

Zloković, Milan, „Integration of the «modulor» into the international modular system”, („Integrisanje «modulora» u internacionalni modularni sistem“). Arhitektura-urbanizam, 6/1960, Beograd, 1960.

Zloković, Milan, „Multiple de module de base. Essai d'une systématisation de nombres préférentiels dans le domaine de la coordination modulaure". Meeting of the International modular group in Bamberg 1961, umnožio Savezni zavod za produktivnost rada, Beograd, 1961.

Zloković, Milan, „Multiples modulaires de préférence. Superposition de résaux modulaires”. Meeting of the International modular group in Paris 1962, umnožio Savezni zavod za produktivnost rada, Beograd, 1962.

Zloković, Milan, „La coordinazione modulare”, Industrializzazione dell'edilizia, Dedalo libri, 139-196, Bari, pp.139-193 